\title{
Effect of high thermal manipulations in early and late embryogenesis on growth of tibia and femur bones of broilers*
}

\author{
Sezai ALKAN¹, Özgür Barıș BİRGÜL²
}

${ }^{1}$ Ordu Üniversitesi Ziraat Fakültesi Zootekni Bölümü, ORDU

${ }^{2}$ Akdeniz Üniversitesi Ziraat Fakültesi Zootekni Bölümü, ANTALYA

Bu çalışma, Akdeniz Üniversitesi Bilimsel Araştırma Projeleri Yönetim Birimi tarafından desteklenmiştir (Proje no: 2010.03.0121.005).

Alınış tarihi: 19 Şubat 2018, Kabul tarihi: 10 Nisan 2018

Corresponding author: Sezai ALKAN, e-posta:sezaialkan61@gmail.com

\begin{abstract}
The aim of this research was to determine the effects of thermal manipulations early and late embryogenesis on growth of tibia and femur bones of broilers. For control group eggs $37.5^{\circ} \mathrm{C}$ and $55 \%$ humidity were applied on the incubation during 19 days. Incubation temperature was increased to $41{ }^{\circ} \mathrm{C}$ and humidity to $65 \%$ for 3 hours on the $8^{\text {th }}$ $-10^{\text {th }}$ days of incubation during early embryogenesis. Similarly, incubation temperature was increased to $41^{\circ} \mathrm{C}$ and humidity to $65 \%$ for 3 hours on the $16^{\text {th }}-18^{\text {th }}$ days of incubation during late embryogenesis. Average tibia bone lengths were determined as $97.57 \mathrm{~mm}, 99.08 \mathrm{~mm}$ and $100.25 \mathrm{~mm}$ for control, early and late embryonic groups, respectively, and significant difference were determined between the average values. Also, male broilers $(100.27 \mathrm{~mm})$ have higher tibia bone length than females $(97.66 \mathrm{~mm})$. The differences between the groups in point of femur bone length was significant, and the highest femur bone length was in the late embryonic group $(70.79 \mathrm{~mm})$, the lowest femur bone length in the control (68.93 $\mathrm{mm}$ ) group.
\end{abstract}

Key words: Broilers, thermal manipulation, growth, tibia-femur bone
Etlik piliçlerde embriyonun erken ve geç gelişim dönemlerinde yapılan yüksek isıl uygulamanın tibia ve femur kemiğinin büyümesine etkileri

\section{Öz}

$\mathrm{Bu}$ çalışmada embriyo geliş̧iminin erken ve geç dönemlerindeki yüksek ısıl uygulamanın tibia ve femur kemiklerinin gelişimine olan etkilerinin belirlenmesi hedeflenmiştir. Bunun için, kontrol grubundaki yumurtalara $37.5^{\circ} \mathrm{C}$ sicaklık ve $\% 55$ nem 19. güne kadar uygulanmıştır. Kuluçkanın erken (8-10. günler) ve geç embriyonik (16-18. günler) dönemlerinde ise günlük 3 saat süreyle yumurtalara $41^{\circ} \mathrm{C}$ sıcaklık ve $\% 65$ nem uygulanması yapılmıştır. Tibia kemik uzunluğu kontrol, erken ve geç embriyonik gruplarında sırasıyla $97.57 \mathrm{~mm}, 99.08$ $\mathrm{mm}$ and $100.25 \mathrm{~mm}$ olarak ölçülmüş olup gruplar arasındaki farklılık önemli bulunmuştur. Tibia kemiği erkeklerde $(100.27 \mathrm{~mm})$ dişilerden (97.66 $\mathrm{mm}$ ) daha uzun olarak belirlenmiștir. Femur kemiği uzunluğu bakımından gruplar arasındaki farklılık önemli bulunmuş olup femur kemiği uzunluğu en fazla geç embryonik $(70.79 \mathrm{~mm})$ grubunda, en düşük ise kontrol grubunda $(68.93 \mathrm{~mm})$ ölçülmüștür.

Anahtar kelimeler: Etlik piliç, ısıl uygulama, büyüme, tibia-femur kemiği 


\section{Introduction}

Chicken meat is an important and cheap source of animal protein for human due to its low fat content, nutritive value and high protein level. Today, a significant increase has been achieved in the production of poultry meat (Warriss, 2010). Increasing the ratio of breast meat, decreasing abdominal fat ratio, improvement of the product quality and product diversity have played an important role in the poultry meat production. In addition to genetic breeding studies, epigenetic adaptation during incubation is used to try to reduce heat stress by high temperature and humidity manipulations in embryonic period in poultry (Yahav, 2004; Yalcin et al. 2005; Narinc et al. 2016). In recent years, applying high temperature and humidity studies has increased in the incubation stage. High temperature and humidity practices in incubation phase increased the resistance of the poultry chickens to heat stress. During the application of heat stress, the temperature threshold of the body changes for heat production and heat dissipation, so the heat stress tolerance of the poultry chickens increases (Yahav, 2000; Nichelmann, 2004). Thermal application studies are basically divided according to incubation stage and postnatal periods. The pre-incubation period is very important period in tems of balancing systems for body temperature. Temperature and humidity of the incubator can cause in the physiological responses of the poultry to high temperature and humidity. Control of early development of the thermoregulatory system during incubation by changes in incubation temperature could be a tool to adapt chicks to higher post-hatch ambient temperatures (Tzschentke, 2007). Higher cyclic incubation temperatures during specific periods of embryogenesis improved the thermotolerance of broilers and reduced the reverse effects of short- or long-term heat stress on broilers (Yalcin et al. 2005; Piestun et al. 2008). The growth rate of the muscle of broilers has displayed an important improvement than body weight improvement (Lilburn, 1994). Developments in the rate of growth of chickens caused many unexpected results, such as an increase in carcass fatness and skeletal diseases (Sullivan, 1994). Besides, genetic selection for fast growth, gender and environmental temperature can affect the skeletal development of poultry (Leterrier and Constantin 1999; Rose et al.
1996; Leeson and Caston, 1993). Yalcin et al. (1995) determined that chicken reared at high temperatures tibia and humerus weight decreased, but the length was not affected. Bruno et al (2000) observed that broiler chickens reared under heat stress conditions indicated a reduction in both the length and width of the tibia, femur and humerus. Also, Eriksen et al. (2003) studied the influence of temperature on bone growth in the chick. Their results indicated that the total skeletal calcium and the true bone length of several long bones vary linearly with the temperature of the chick embryo by as much as $20 \%$ per degree centigrade.

The objective of the research was to evaluate the effects of high thermal manipulations early (EE $8-10$ days) and late (LE16-18 days) embryogenesis on growth of tibia and femur bones of broilers.

\section{Material and Method}

This study was conducted in summer season between June and July months during 6 weeks of age. Eggs used in this study were obtained from commercial firms. Eggs were stored for one day at $16-18^{\circ} \mathrm{C}$ and $70-75 \%$ humidity conditions. Eggs were randomly divided into 3 groups. For control group eggs $37,5{ }^{\circ} \mathrm{C}$ and 55 $\%$ humidity were applied on the incubation during 19 days. Then, incubation temperature was increased to $41^{\circ} \mathrm{C}$ and humidity to $65 \%$ for 3 hours on the $8^{\text {th }}-10^{\text {th }}$ days of incubation during early embryogenesis. Similarly, incubation temperature was increased to $41^{\circ} \mathrm{C}$ and humidity to $65 \%$ for 3 hours on the $16^{\text {th }}-18^{\text {th }}$ days of incubation during late embryogenesis. (Bruzual et al. 2000). The eggs were turned through $270^{\circ}$ automatically every hour. At the 18th day of incubation, the eggs were transferred to $37.5^{\circ} \mathrm{C}$ and $55 \%$ humidity conditions. trays. Hatched chicks were wingbanded and individually weighed at hatching. The chicks were fed with a diet consisting of $12.50 \mathrm{MJ} \mathrm{kg}^{-1}$ metabolic energy and $210 \mathrm{~g}$ crude protein $\mathrm{kg}^{-1}$ ad libitum and unlimited water was supplied during the experiment. At the end of the experiment at random from each group of 10 males and 10 females broilers selected, and the femoral and tibial lengths and widths were measured in these animals. Much of the adhering tissue was removed from each bone with scissors and blades. The length and width of each bone was measured with dijital caliper $(\mathrm{mm} \pm 0,01)$ (Applegate and Lilburn, 2002; Birgul et al. 2011). 


\section{Statistical methods}

Following model was used for statistical analyses:

$$
Y_{i j k}=\mu+g_{i}+c_{j}+e_{i j k}
$$

where $Y_{i j k}$ represents the observation values, $\mu$ was the overall mean, $g_{i}$ is the effect of the $i-t h$ manipulation, $c_{j}$ is the effect of the $\mathrm{j}$-th gender and $\mathrm{e}_{\mathrm{ijk}}$ is the error term, $\sim \mathrm{N}(0, \sigma 2 \mathrm{e})$.

\section{Findings and Discussion}

Temperature and relative humidity values in terms of weeks were presented in Table 1 . The effects of thermal manipulations and gender on length and width of tibia and femur bones were given in Table 2 and 3 . Temperature and relative humidity values were ranged between $29.79-32.46{ }^{\circ} \mathrm{C}$ and $\%$ 42.73-74.82, respectively.

Table 1 . Weekly temperature $\left({ }^{\circ} \mathrm{C}\right)$ and relative humidity $(\%)$ values

\begin{tabular}{ccc}
\hline Week & Temperature \pm SE 1 & ${\text { Relative humidity } \pm \text { SE }^{1}}^{1}$ \\
2 & $30.54 \pm 0.17$ & $65.90 \pm 3.53$ \\
3 & $30.93 \pm 0.18$ & $73.11 \pm 4.31$ \\
4 & $30.22 \pm 0.18$ & $74.82 \pm 3.52$ \\
5 & $31.74 \pm 0.22$ & $70.85 \pm 4.52$ \\
6 & $32.46 \pm 0.28$ & $42.73 \pm 3.48$ \\
\hline
\end{tabular}

1Standard error

As seen in Table 2, the length of tibia was $97.57 \mathrm{~mm}$ in the control, $99.08 \mathrm{~mm}$ in the early embryogenesis and $100.25 \mathrm{~mm}$ in late embryogenesis groups, respectively. Average length of tibia of early and late embryogenesis was significantly longer than those of control group $(\mathrm{P}<0.05)$. For all that, significant difference between the genders was found, and tibia length was significantly longer in males $(100.27 \pm 0.62 \mathrm{~mm})$ than females $(97.66 \pm 0.62 \mathrm{~mm})$. Also, there was significant difference among the groups in terms of tibia widths, and tibia width $(9.84 \mathrm{~mm})$ in the late embryogenesis group was higher than those of control $(9.26 \mathrm{~mm})$ and early embryogenesis $(9.31 \mathrm{~mm})$ groups. As presented in Table 3, difference among the groups in terms of lengths of femur was found significant $(\mathrm{P}<0.05)$, and highest length of femur value was determined in late embryogenesis group $(70.79 \mathrm{~mm})$. In contrast, the lowest length of femur value was found in control group $(68.93 \mathrm{~mm})$. Also, there was determined significant difference between the genders, and length of femur of males was higher than that of females. However, difference among the groups in respect to widths of femur was not significant, in contrast, males have higher value $(10.34 \mathrm{~mm})$ than those of females (9.16mm).

Kocabagli (2001) reported that lengths of tibia bone vary between $89.4-92.2 \mathrm{~mm}$. Also, Barreiro et al.(2011) found that lengths of tibia bone were $32.5 \mathrm{~mm}, 54.36 \mathrm{~mm}$ and $80.68 \mathrm{~mm}$ in $8^{\text {th }}, 22^{\text {th }}$ and $42^{\text {th }}$ days of age, respectively. Yalcin et al.(1995) stated that high temperatures reduced tibia bone weight, however, did not affect the length of tibia bones. Again in another study, effects of genotype, age of parent and gender on morphological characteristics and composition of tibia bone were investigated. Tibia lengths of male and females broilers at 32 and 48 days of age were changed between 88.56-98-50 $\mathrm{mm}$ and between 115-118 mm changed, respectively. In contrast, tibia widths of male and females broilers at 32 and 48 days of age were changed between 6.20-6-50 $\mathrm{mm}$ and between 8.44-9.07 mm (Yalcin et al. 2001). In a study by Quarantelli et al. (2007), lengths of femur bone at 21, 41 and 61 days of age as 51.40$54.57 \mathrm{~mm}, 75.50-79.87 \mathrm{~mm}$ and $90.50-97.37 \mathrm{~mm}$, but lengths of tibia bone as $72.47-96.0 \mathrm{~mm}, 107.5$ $114.5 \mathrm{~mm}$ and $132.43-140.83 \mathrm{~mm}$ were determines, respectively. High ambient temperature reduced growth of femur and tibia bones of broilers, but did not affect bone fracture resistance, and lengths of femur and tibia bone of broilers grown in low ambient temperature $\left(15^{\circ} \mathrm{C}\right)$ was significantly lower than those of grown in optimum ambient temperature $\left(24^{\circ} \mathrm{C}\right)$, however there was no significant difference between the ambient temperature groups in point of width of femur and tibia bones (Bruno et al.(2000, 2007). Shim and Pesti (2011) stated that application of different temperatures during incubation had no significant affect on length of the tibia bone for broilers. Curek (2010) reported that there was no significant difference between the low and rapidly growing 
broilers in respect to lengths of tibia, and tibia lengths were determined $107.19 \mathrm{~mm}$ for slow growing and $106.44 \mathrm{~mm}$ for rapid growing broilers. In the same study, there was significant difference between the winter $(107.90 \mathrm{~mm})$ and spring $(109.97 \mathrm{~mm})$ seasons in terms of lengths of tibia bones. Thermally treated eggs of broilers during late embryogenesis (EL 14-17 days), incubation temperature was increased to $41^{\circ} \mathrm{C}$ for 4 hours by Badran et al. (2012). The authors concluded that this process provides epigenetic adaptations necessary to deal with the high temperature, and thermally treated group has higher tibia length than that of control group. In another study, length and width of tibia femur bone of broilers from hatching to at 43 days of age were measured weekly. Significant difference was found between the male and females in point of length of tibia bone at 15 and 35 days of age, and similarly, significant difference was determined between male and females in respect to length of femur bone at 43 days of age. In addition, significant difference was found between male and females in point of width of tibia and femur bones at 28 and 43 days of age in the same study (Applegate and Lilburn, 2002).

Table 2. Effect of thermal manipulation and gender on length and width of tibia bone (mm)

\begin{tabular}{|c|c|c|c|c|c|c|}
\hline \multirow{2}{*}{ Groups } & \multicolumn{3}{|c|}{ Length of tibia (mm) } & \multicolumn{3}{|c|}{ Width of tibia (mm) } \\
\hline & Left ${ }^{*}$ & Right* & Average $\pm \mathrm{SE}$ & Left $^{*}$ & Right* & Average $\pm \mathrm{SE}$ \\
\hline Control & $98.23 \pm 0.65$ & $96.90 \pm 1.00$ & $97.57 \pm 0.76^{b}$ & $9.32 \pm 0.17 \mathrm{~b}$ & $9.21 \pm 0.19$ & $9.26 \pm 0.16^{b}$ \\
\hline $\mathrm{EE}^{1}$ & $99.25 \pm 0.65$ & $98.90 \pm 1.00$ & $99.08 \pm 0.76^{\mathrm{a}}$ & $9.13 \pm 0.17 \mathrm{~b}$ & $9.49 \pm 0.19$ & $9.31 \pm 0.16^{b}$ \\
\hline $\mathrm{LE}^{2}$ & $100.15 \pm 0.65$ & $100.34 \pm 1.00$ & $100.25 \pm 0.76^{\mathrm{a}}$ & $9.83 \pm 0.17 \mathrm{a}$ & $9.86 \pm 0.19$ & $9.84 \pm 0.16^{\mathrm{a}}$ \\
\hline \multicolumn{7}{|l|}{ Gender } \\
\hline Male & $100.69 \pm 0.53^{\mathrm{a}}$ & $99.83 \pm 0.82$ & $100.27 \pm 0.62^{a}$ & $9.97 \pm 0.14^{\mathrm{a}}$ & $10.05 \pm 0.15^{a}$ & $10.01 \pm 0.13^{\mathrm{a}}$ \\
\hline Female & $97.73 \pm 0.53^{b}$ & $97.59 \pm 0.82$ & $97.66 \pm 0.62^{b}$ & $8.88 \pm 0.14 \mathrm{~b}$ & $8.99 \pm 0.15^{b}$ & $8.93 \pm 0.13^{b}$ \\
\hline
\end{tabular}

${ }^{1}$ Early embryogenesis, ${ }^{2}$ Late embryogenesis; * mean $\pm \mathrm{SE}$, a,b Means in column, with different letters differ significantly at $(\mathrm{P}<0.05)$

Table 3. Effect of thermal manipulation and gender on length and width of femur bone ( $\mathrm{mm}$ )

\begin{tabular}{|c|c|c|c|c|c|c|}
\hline \multirow{2}{*}{ Groups } & \multicolumn{3}{|c|}{ Length of tibia (mm) } & \multicolumn{3}{|c|}{ Width of tibia $(\mathrm{mm})$} \\
\hline & Left $^{*}$ & Right $^{*}$ & Average \pm SE & Left ${ }^{*}$ & Right* & Average $\pm \mathrm{SE}$ \\
\hline Control & $68.96 \pm 0.56$ & $68.90 \pm 0.57$ & $68.93 \pm 0.55^{b}$ & $9.80 \pm 0.16$ & $9.71 \pm 0.15$ & $9.76 \pm 0.15$ \\
\hline $\mathrm{EE}^{1}$ & $69.17 \pm 0.56$ & $69.40 \pm 0.57$ & $69.28 \pm 0.55^{\mathrm{ab}}$ & $9.64 \pm 0.16$ & $9.49 \pm 0.15$ & $9.57 \pm 0.15$ \\
\hline $\mathrm{LE}^{2}$ & $70.74 \pm 0.56$ & $70.83 \pm 0.57$ & $70.79 \pm 0.55^{\mathrm{a}}$ & $9.86 \pm 0.16$ & $9.99 \pm 0.15$ & $9.93 \pm 0.15$ \\
\hline \multicolumn{7}{|l|}{ Gender } \\
\hline Male & $70.65 \pm 0.45^{\mathrm{a}}$ & $70.89 \pm 0.46^{a}$ & $70.78 \pm 0.45^{a}$ & $10.34 \pm 0.13^{\mathrm{a}}$ & $10.33 \pm 0.12^{\mathrm{a}}$ & $10.34 \pm 0.12$ \\
\hline Female & $68.59 \pm 0.45^{b}$ & $68.53 \pm 0.46^{b}$ & $68.56 \pm 0.45^{b}$ & $9.19 \pm 0.13^{b}$ & $9.13 \pm 0.12^{\mathrm{b}}$ & $9.16 \pm 0.12^{b}$ \\
\hline
\end{tabular}

${ }^{1}$ Early embryogenesis, ${ }^{2}$ Late embryogenesis; * mean $\pm S E$, a,b Means in column, with different letters differ significantly at $(\mathrm{P}<0.05)$

\section{Conclusion}

It was concluded that raising the incubation temperature for a short period ( 3 hours/day) at the early or late part of embryonic development ( day 8 to 10 and day 16 to 18 day of incubation) induced beneficial thermal epigenetic physiological changes. This epigenetic thermal adaptation could be employed for coping with post-hatch heat stress. The highest value for length of tibia bone was in late embryogenesis period, whereas lowest width of tibia bone was obtained in this group. In terms of length of femur bone, there was significant difference between the control and late embryogenesis groups, but no significant differences were detected between the groups in terms of width of femur bones. Obtained results in this study and the findings of the literature show some differences in terms of length and width of tibia and femur bones. Applied different temperature and humidity values and also applying different times have influenced differently obtained results. Consensus could not be reached exactly studies on this subject. Therefore, more research is needed to determine the effects of application of temperature and humidity on the development of skeletal and bone during incubation stage. 


\section{Acknowledgements}

This study was financially supported by the Scientific Research Projects Unit of Akdeniz University under the project number of 2010.03.0121.005.

\section{References}

Applegate, T.J., Lilburn, M.S., 2002. Growth of the femur and tibia of a commercial broiler line. Poultry Science, 81:1289-1294.

Badran, A,M,, Desoky, A., Abou-Eita, E.M., Stino, F.K., 2012. Epigenetic thermal adaptation of chickens during late embryonic development. Egyptian Poultry Science, 32: 675-689.

Barreiro, F.R., Baraldi-Antoni, S.M., Do Amaral, L.A., Barbosa, J.C., Girardi, A.M., Pacheco, M.R., Amoroso, L., 2011. Determination of broiler femur parameters at different growth phases. International Journal of Poultry Science, 10: 849-853.

Birgul, O.B., Mutaf, S., Alkan, S., 2011. Farklı tünek sistemlerinin etlik piliclerde tibia ve femur kemiklerinin morfolojik ve kimyasal özelliklerine etkileri. Kafkas Universitesi Veteriner Fakültesi Dergisi, 17:773779.

Bruno, L.D.G., Furlan, R.L., Malheiros, E.B., Macari, M., 2000. Influence of early quantitative food restriction on long bone growth at different environmental temperatures in broiler chickens. British Poultry Science, 41: 389-394.

Bruno, L.D.G., Luquetti, B.C., Furlan, R.L, Macari, M., 2007. Influence of early qualitative feed restriction and environmental temperature on long bone development of broiler chickens. Journal of Thermal Biology, 32: 349-354.

Bruzual, J.J., Peak, S.D., Brake, J., Peebles, E.D., 2000. Effects of relative humidity during incubation on hatchability and body weight of broiler chicks from young breeder flocks. Poultry Science, 79: 827-830.

Curek, I.D., 2010. Genotip, Yetistirme Sistemi ve Mevsimin Antalya Kosullarinda Etlik Pilic Refahına Etkilerinin Araştırılması. Akdeniz Üniversitesi Fen Bilimleri Enstitüsü (basılmamış), Doktora Tezi, Antalya, 115 sayfa.

Eriksen, M.S., Haug, A., Torjesen, P.A., Bakken, M., 2003. Prenatal exposure to corticosterone impairs embryonic develepment and increases fluctuating asymmetry in chickens (Gallus gallus domesticus). British. Poultry Science, 44: 690-697.

Kocabagli, N., 2001. The effect of dietary phytase supplementation at different levels on tibial bone characteristics and strength in broilers. Turkish Journal Animal and Veterinary Science, 25:797-802.
Leeson, S., Caston, L.J., 1993. Does envirenmental temperature influence body weight:shank length in Leghorn Pullets? Journal Applied Poultry Research, 2: 245248.

Leterrier, C., Constantin, P., 1999. Early bone growth in chickens genetically selected for a high and low growth rate. Growth Development Aging, 63: 75-84.

Lilburn, M.S., 1994. Skeletal growth of commercial poultry species. Poultry Science, 73: 897-903.

Narinc, D., Erdoğan, S., Tahtabicen, E., Aksoy, T., 2016. Effects of thermal manipulations during embryogenesis of broiler chickens on developmental stability, hatchability and chick quality. Animal, 10: 13281335.

Nichelmann, M., 2004. Perinatal epigenetic temperature adaptation in avian species: comparison of turkey and muscovy duck. Journal Thermal Biology, 29: 613619.

Piestun, Y., Shinder, D., Ruzal, M., Halevy, O., Brake, J., Yahav, S., 2008. Thermal manipulations during broiler embryogenesis: Effect on the acquisition of thermotolerance. Poultry Science, 87:1516-1525.

Quarantelli, A., Cacchioli, A., Romanelli, S., Righi, F., Alpigiani, I., Gabbi, C. , 2007. Effects of different levels of dietary biotin on the performance and bone structure of broilers. Italian Journal Animal Science, 6: 517.

Rose, N., Constantin, P., Leterrier, C., 1996. Sex differences in bone growth of broiler chickens. Growth Development Aging, 60: 49-59.

Sullivan, T.W., 1994. Skeletal problems in poultry: Estimated annual cost and descriptions. Poultry Science, 73: 879-882

Shim, M.Y., Pesti, G.M., 2011. Effects of incubation temperature on the bone development of broilers. Poultry Science, 90:1867-1877.

Tzschentke, B., 2007. Attainment of thermoregulation as affected by environmental factors. Poultry Science, 86:1025-1036.

Warriss, P.D. 2010. Meat Science. In an introductory text, pp. 234. Oxford: CABI, N. Y.

Yalcin, S., Zhang, X., Mcdaniel, G.R., Kuhlers, D.L., 1995. Effect of selection for high or low incidence of tibial dyschondroplasia for seven generations on live performance. Poultry Science, 74: 1411-1417.

Yalcin, S., Ozkan, S., Turkmut, L., Siegel, P.B., 2001. Responses to heat stress in commercial and local broiler stocks.1. Performance traits. British Poultry Science, 42:149-152 
Yalcin, S., Ozkan, S., Cabuk, M., Buyse, J., Decuypere, E., Siegel, P.B., 2005. Pre and postnatal conditioning induced thermotolerance on body weight, physiological responses and relative asymmetry of broilers originating from young and old breeder flocks. Poultry Science, 84: 967-976.
Yahav, S., 2000. Domestic fowl-strategies to confront environmental conditions. Avian Poultry Biology Reviews, 11: 81-95.

Yahav, S., Collin, A., Shinder, D., Picard, M., 2004. Thermal manipulations during broiler chick embryogenesis: Effects of timing and temperature. Poultry Science, 83:1959-1963. 